\title{
TERRITÓRIOS DE EXCEÇÃO: REDES DE INFRAESTRUTURA NA CIDADE DE SÃO PAULO
}

\author{
Katia Bomfim Pestana \\ Faculdade de Arquitetura e Urbanismo da Universidade de São Paulo \\ Orientadora: Profa. Dra. Regina Maria Prosperi Meyer \\ kpestana@usp.br
}

\section{RESUMO}

O setor de infraestrutura de serviços no Brasil e, especificamente na cidade de São Paulo, tem sua história marcada pela ocupação de territórios de exceção no tecido urbano da cidade. As redes de serviços encontram grande capilaridade na malha urbana onde estão inseridas e hoje, com o brutal crescimento da mancha urbana, suas faixas funcionais atravessam bairros densamente povoados deixando vazios significativos, principalmente quando comparados às escassas áreas livres existentes nesses locais.

A instalação dessas redes, levando-se em conta somente seus aspectos funcionais e de segurança, gera uma sequência de espaços residuais que muitas vezes acabam por aumentar os riscos, já que não estão inseridas no contexto urbano onde estão instaladas. A faixa non aedificandi de um oleoduto e uma linha de alta tensão é tratada de maneira exemplar, como uma das diversas redes de infraestrutura instaladas na malha urbana da cidade de São Paulo.

Palavras-chave: Infraestrutura urbana; Metrópole de São Paulo; oledutos; linhas de alta tensão.

\begin{abstract}
The service infrastructure sector in Brazil, and specifically in the city of São Paulo, has its history marked by the occupation of territories of exception in the urban fabric of the city. The service networks find great capillarity in the urban network where they are inserted and today, with the brutal growth of the urban spot, its functional bands cross densely populated neighborhoods leaving significant voids, especially when compared to the scarce free areas in these places.
\end{abstract}

The establishment of these infrastructural networks, taking into account only their functional and safety aspects, generate a sequence of residual space which often contributes to increased risk factors since they are not inserted within the urban context of their locations. The range of a pipeline and a high voltage line is treated in an exemplary manner, as one the city of São Paulo's various infrastructural networks within its urban grid.

Key words: Urban network infrastructure; São Paulo Metropolitan area; pipelines; power transmission line. 


\section{INTRODUÇÃO}

O setor de infraestrutura de serviços no Brasil e, especificamente na cidade de São Paulo, tem sua história marcada pela ocupação de territórios de exceção no tecido urbano da cidade. As redes de serviços, como os oleodutos, as adutoras, as linhas de alta tensão, os rios e canais de drenagem, encontram grande capilaridade na malha urbana onde estão inseridas e hoje, com o brutal crescimento da mancha urbana, suas faixas funcionais - que anteriormente passavam em áreas não urbanizadas - atravessam bairros densamente urbanizados deixando vazios significativos, principalmente quando comparados às escassas áreas livres existentes nesses locais.

Nessas condições, essas faixas non aedificandi se relacionam com uma das questões prioritárias do projeto da cidade contemporânea: garantir a melhoria do meio ambiente urbano, recuperar espaços deteriorados para a habitação, melhorar a mobilidade urbana, ampliar as alternativas de circulação de pedestres e ciclovias, e estabelecer relações dessas áreas com a infraestrutura viária e edilícia local, de modo a garantir o adensamento necessário e o convívio público desejado.

A capacidade de estruturação e organização do tecido urbano pelas redes de infraestrutura parece evidente frente a outros elementos urbanos mais mutáveis - como, por exemplo, os edifícios, que se transformam a partir de regulamentações do uso do solo, alterando a sua configuração original ao longo do tempo. Contudo, não podem ser encaradas como redes independentes, dimensionadas a partir da maximização do seu funcionamento e destacadas dos planos urbanísticos previstos para as áreas de transformação urbana.

(...) a incapacidade de aceitar esse papel positivo das infraestruturas na conformação de uma paisagem territorial, é consequência de uma postura autista de seus construtores e uma resposta crescente de defesa contra a agressão a outros valores que sua construção pode representar. (VALLEJO, 2008).

As redes de infraestrutura são entendidas aqui como capital urbano fixo - medida de sua capacidade e limitação de crescimento - , pois requerem ações integradas com elevado custo de investimentos e de alto impacto no arranjo espacial pré-existente (ou não) da cidade. Essas infraestruturas inseridas em um tecido extremamente mutável, como são as cidades contemporâneas, podem funcionar como um dos principais elementos articuladores do espaço urbano e são fundamentais por carregarem um significado simbólico para os cidadãos: são elas que fazem o transporte de serviços públicos básicos, seja água, eletricidade, gás, petróleo, telefonia, passageiros, cargas, etc. A existência dessas linhas em áreas de urbanização consolidada pode ser entendida como uma espécie de 'resíduo' que nasceu quando o antigo território urbanizou-se e, posteriormente, cresceu. Fernando de Mello Franco diz que essas permanências materiais a transpassar o tempo contém uma densidade histórica que as diferencia pelo valor de uso, pelo valor de referência e pelo valor de memória, que conjuntamente Ihes conferem um caráter estruturante em relação às formas de uso do território. (FRANCO, 2001).

A complexidade do tema certamente vincula-se à forma de produção do Espaço Urbano, explicitadas pelas demandas sociais e econômicas, técnicas e tecnológicas que tiveram ao longo do tempo sua história na ocupação dos diversos trechos da cidade. Ao falarmos da dinâmica dessas redes a partir da escala metropolitana (ou mesmo macrometropolitana) e dentro da lógica setorial de cada uma delas, o 'risco' deixado pela sua passagem nos aproxima de questões relacionadas à distribuição desigual das infraestruturas sobre o território e às formas de apropriação do urbano como produto social e expressam, de maneira determinante, a produção da sociedade no espaço da cidade.

Graham e Marvin (2001) descrevem inúmeras situações onde os serviços públicos que, a princípio, deveriam estar disponíveis a todos os cidadãos a custos similares são, na nova etapa da organização da sociedade em rede, benefícios apenas para alguns. Os serviços essenciais passam a ser tratados como mercadorias e o acesso a eles torna-se possível somente a quem pode pagar. A ideia, conforme os autores, é que as redes de infraestrutura - que, em sua essência, seriam igualitárias e integradoras do espaço da cidade (por trazer coesão ao território) - tornam-se, nesta nova etapa do capitalismo, redes privatizadas a serviço de usuários restritos ('costumers').

Há, desde há muito, questões que envolvem o financiamento, as políticas públicas, segurança, vínculos preexistentes tanto no que se refere ao território, como na forma de negociação do Estado brasileiro na gestão dessas redes. Muitas das redes e calhas técnicas, que são remanescentes de um período no qual a sua instalação precedeu a urbanização de seu entorno, dizem da forma como foram planejadas e como o plano inicial, o de fornecimento de energia, foi sendo executado sempre a reboque da crescente demanda e misturou-se aos espaços habitáveis da cidade.

A partir da leitura dessas estruturas sobre o espaço físico da cidade, a tentativa de discernir tipologias de apropriação e aproximação junto a essas faixas non aedificandi busca estabelecer alguns padrões de 
ocupação, desde áreas onde esses vazios aparecem como ordenadores até lugares que ficam supostamente escondidos e inabitáveis, mas que cumprem a sua função simbólica na paisagem.

A ênfase dada está na observação singular de cada lugar por onde passam essas redes e, de especial interesse, quando confrontadas com as urbanizações precárias, onde os espaços aptos a se exercer a urbanidade são praticamente inexistentes. Nesses lugares, a faixa de servidão torna-se um vetor claro de espaço potencial a ser incorporado pelas tênues relações espaciais existentes.

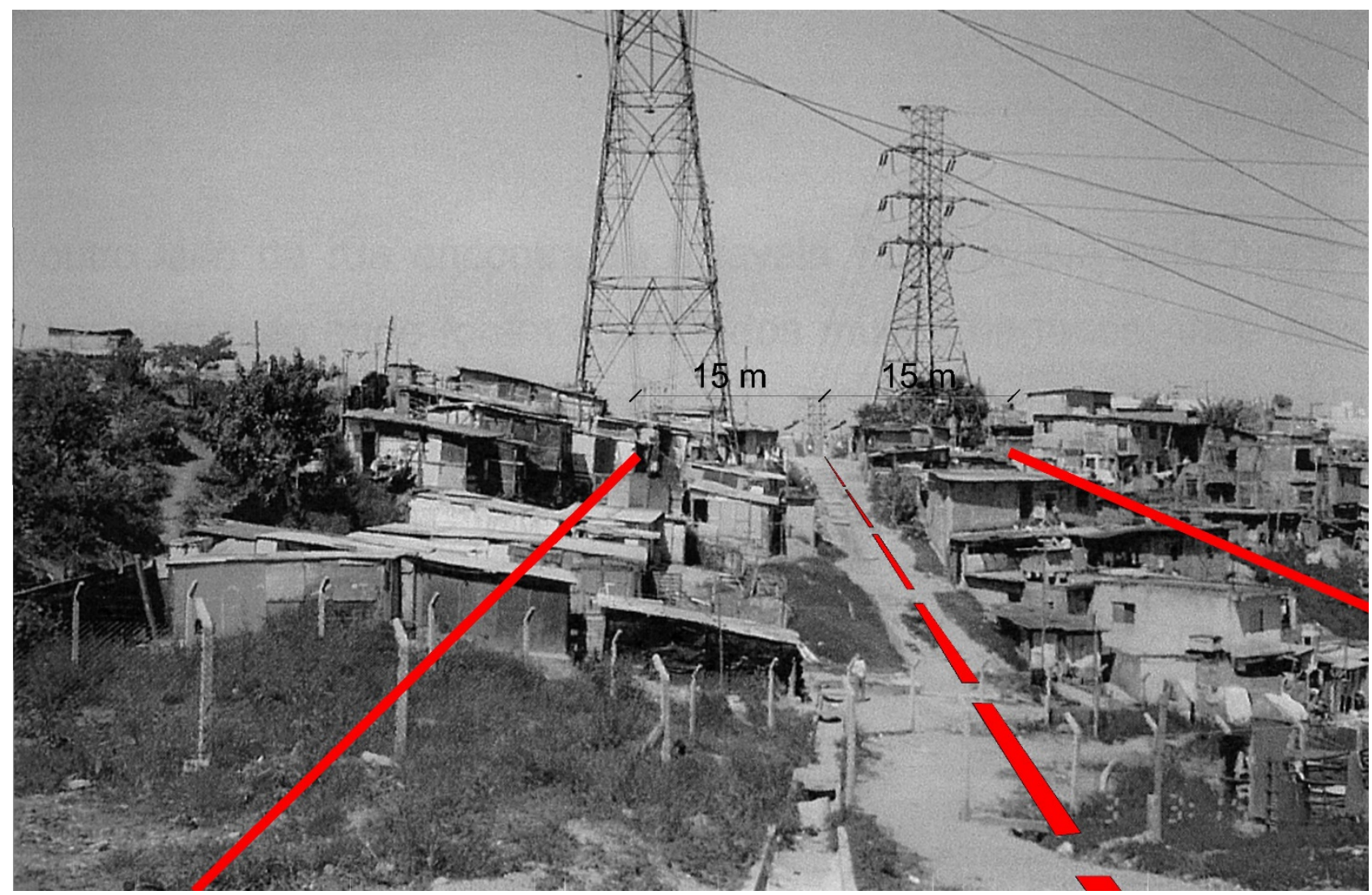

Faixa de 15 metros de cada lado, a partir do eixo do oleoduto. Projeto Convivência e Parceria (2001).

Elaboração: Katia B. Pestana

O sentido do lugar como referência para compreender o que acontece ao redor dessas infraestruturas pode ser tomado como um conceito que vem acompanhado da relação entre o espaço econômico unívoco da era pós-industrial, e uma escala próxima, de fortalecimento e reconhecimento da identidade dos indivíduos que vivem em um determinado espaço geográfico - global e local. A ênfase no lugar desperta o pensamento em direção ao seu reverso, ao que está muito distante, que ultrapassa a barreira das relações sociais e espaciais locais, abrangendo escalas de observação e operação que se distanciam cada vez mais dos habitantes e tornam-se instâncias quase abstratas, como o funcionamento de uma engrenagem que esgarça as relações existentes entre os cidadãos. No entanto, estamos lidando de maneira estreita com o lugar, onde as referências e seus desdobramentos estão inseridos nas relações que temos com a cidade no uso cotidiano, vínculos temporais e espaciais estabelecidos com o que está próximo.

$\mathrm{Na}$ intenção de trabalhar com escalas diferentes, que conformam e explicitam essas infraestruturas, será entre o espaço entendido como relações que se fazem de fora para dentro, ou seja, no eixo do desenvolvimento tecnológico, e a partir de referências e regulações que interferem na conformação dessas redes na cidade, e o seu contrário, que se fará a leitura e a análise que de certa forma explicitam as relações do lugar, enfatizando como essas infraestruturas, que incidem sobre esses lugares, são parcelas dessas percepções que se constroem no espaço de cada um, e como elas poderiam criar territórios urbanizados e melhores do ponto de vista de seu impacto ambiental.

De acordo com Dematteis (2004), a escolha da escala para a investigação dos sistemas urbanos é uma forma de análise que deve ser aprofundada, porque "a escala seleciona os sujeitos, os pontos de vista pertinentes, os temas, os problemas, os dados, as representações e, em definitivo, os métodos e as categorias conceituais". O que os une é um comportamento que está sempre se referindo ao local, ou seja, ao território urbano de cada cidade, onde aparecem conflitos e interesses diferenciados. Os projetos, os conflitos, os 
êxitos, os fracassos, as dificuldades, os sonhos são os dados - ou indícios - que é preciso recolher sobre o terreno para obter esse conhecimento.

Cecília Scoppetta (2012) nos diz da falta de comunicação entre os setores que "constroem" as infraestruturas e o poder público como ordenador dessas intervenções. Ao analisar a cidade de Roma e sua área metropolitana a partir dos anos 1980, a autora mostra como muitas legislações setoriais foram feitas em forma de plano de ocupação - medidas que resguardam o tráfico urbano, a poluição sonora, o transporte público, etc. -, mas não se comunicam com as leis ordinárias que regem a cidade e, por serem especializadas, acabam por se tornar uma invariável no sistema de ordenação do território. Trata-se de uma reconhecida dissociação entre a lógica técnica da rede de infraestrutura instalada e os instrumentos de regulação do uso do solo utilizados pelo poder público.

A percepção destas questões serve para melhor cercar o objeto de estudo e, de alguma maneira, ir compreendendo as forças políticas que estão em jogo ao estabelecer como recorte um 'fragmento' da Metrópole de São Paulo, estruturado por um oleoduto e uma linha de alta tensão, e que condensam, em si, o poderio do Capital (combustível e eletricidade), várias escalas de interferência (o federal, o estadual, o metropolitano e o municipal) e, principalmente, populações de nível socioeconômico muito diversas.

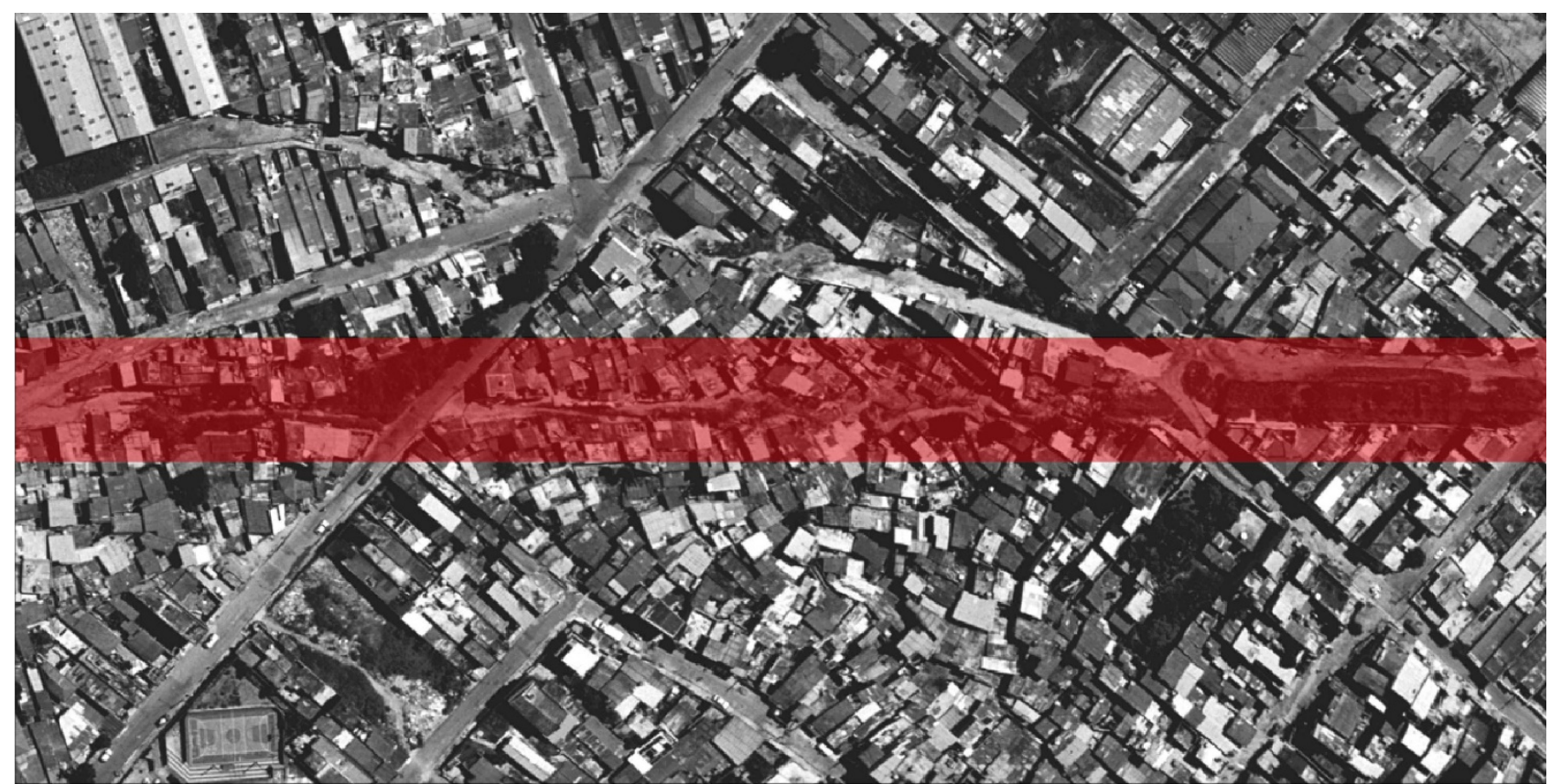

Faixa de 50 metros. Projeto Convivência e Parceria (2001).

Elaboração: Katia B. Pestana

\section{A INFRAESTRUTURA E A LEI}

Conforme Herce Vallejo (2002), há muito que se aperfeiçoar e avançar no diálogo entre infraestrutura e urbanismo. Se houve, na cidade do séc. XIX, o desenvolvimento dessas redes como suporte técnico e constitutivo da construção do território, hoje, com a extrema especialização técnica — inclusive nos aspectos de controle à segurança, com a engenharia de projeto das infraestruturas urbanas trabalhando com coeficientes de segurança cada vez mais altos, a fim de garantir uma 'super' eficiência dos sistemas técnicos instalados na cidade - , elas passam a ser desenhadas somente a partir de seus parâmetros funcionais, econômicos e orçamentários se distanciando da ideia de suporte, que viabilizaria a inter-relação entre os fatores técnicos e o desenho urbano.

O impacto gerado por uma faixa non aedificandi compartilhada entre um oleoduto da Petrobrás (Oleoduto Barueri-Utinga, OBATI, que liga o Terminal de Barueri ao de Utinga, em São Caetano do Sul, passando subterrâneo por uma faixa de $50 \mathrm{~km}$ pelas regiões Oeste, Sul e Sudeste da Grande São Paulo) e uma linha de alta tensão (linha de transmissão elétrica da CTEEP Xavantes - Anhanguera, que atravessa a região oeste e sul da cidade de São Paulo, com $21 \mathrm{~km}$ de extensão) torna explícita a implicação da passagem dessas redes em seus bairros contíguos, identificando situações onde o vazio da faixa de domínio poderia servir como suporte físico para uma integração com a ocupação existente, melhorando o espaço urbano no local. 
Por essas redes estarem submetidas, obrigatoriamente, a condições de segurança estabelecidas pelas normas setoriais, os órgãos de planejamento não incorporam seu vazio 'funcional' a um plano mais amplo de agenciamento dos espaços livres da cidade.

A partir da delimitação desse objeto, justificado como uma questão urbana contemporânea, a pesquisa procura multifacetar alguns critérios de leitura e análise, centrando-se em sistematizar a inserção do OBATI e da AT XAVANTES na cartografia da cidade de São Paulo, sobretudo nos Plano Diretor de São Paulo e nos Planos Diretores dos municípios por onde ele passa, a fim de identificar conexões possíveis entre as diretrizes urbanísticas ditadas pelos planos e os 'eventos' urbanos em torno da faixa non aedificandi gerada pela passagem do duto.

Ao falar de infraestrutura de serviços, os planos diretores dos municípios são bastante genéricos, não enfrentando, por exemplo, as estruturas das linhas de alta tensão ou oleodutos, seja no que se refere ao conjunto de áreas urbanas ocupadas por elas, seja no provisionamento de ações que possam de alguma forma integrar os serviços e as concessionárias à gestão de espaços na cidade. A ingerência do poder público sobre essas áreas é um dos componentes na configuração dos instrumentos legais ligados à propriedade privada e na forma como essas atividades se instalaram no Brasil.
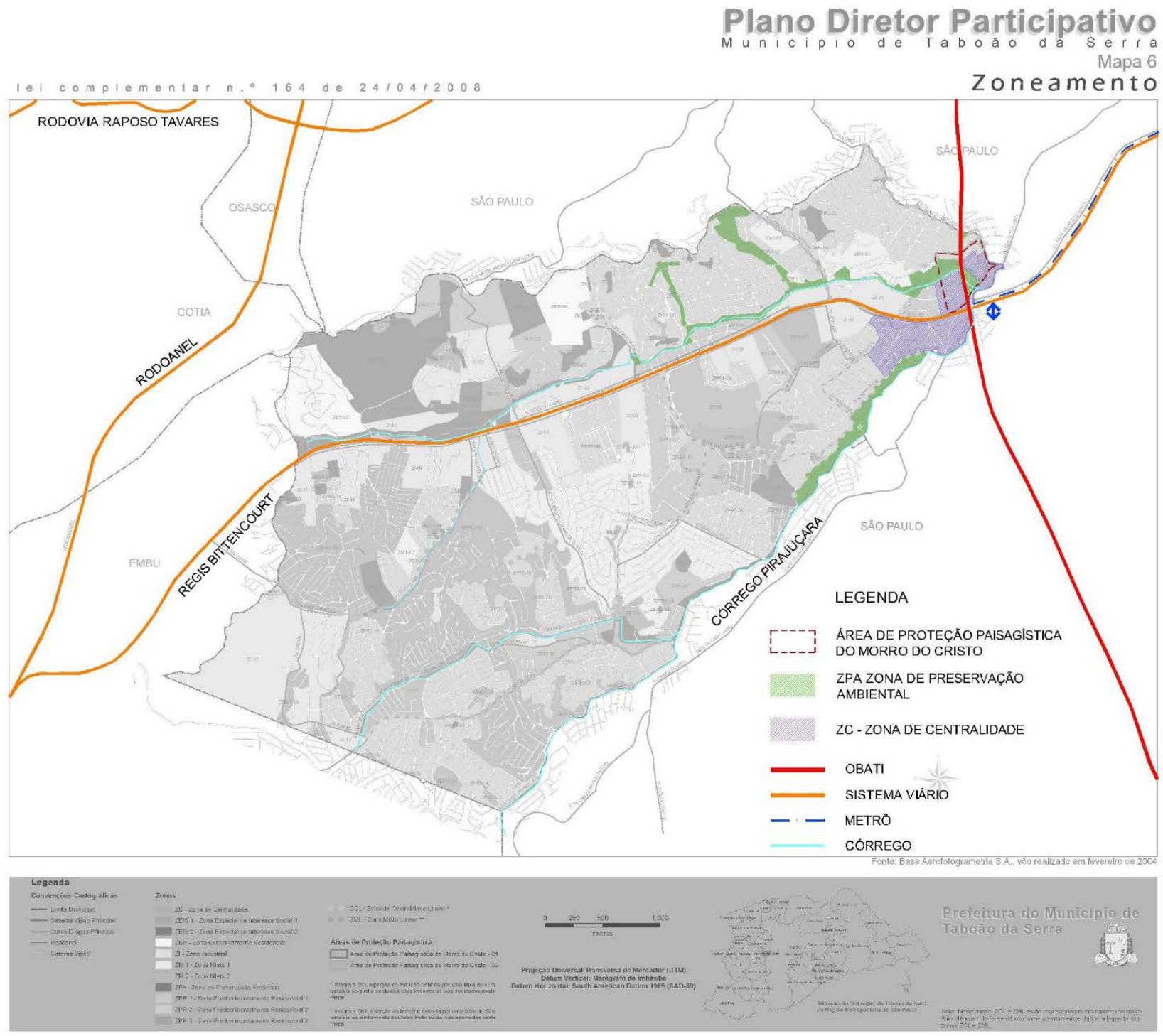

TABOÃO DA SERRA. Exemplo de análise feita em cima dos mapas dos planos diretores dos municípios. A área central é exatamente aonde passa a faixa de alta tensão e o OBATI. Elaboração: Katia B. Pestana, 2010.

A população que vive às margens do OBATI e da AT habita em municípios e, embora de forma alheia às regulamentações de uso e ocupação do solo, está submetida à legislação municipal. Há ainda os planos 
diretores de cada município, principalmente o de São Paulo, que insinua um corredor verde por onde corre o OBATI e a linha de alta tensão e, significamente, tangencia áreas reservadas às Operações Urbanas e às ZEIS, aproximando-se de discussões polêmicas a respeito das políticas para a região metropolitana de São Paulo.

No novo Plano Diretor do Município de São Paulo (2014) ocorreram alguns avanços ao tratar diretamente de questões de infraestrutura de serviços, propondo no texto da lei ações de mapeamento, integração e compartilhamento dos diversos serviços públicos como um dos aspectos relevantes na construção da paisagem urbana. Pela primeira vez, no novo Plano, as faixas de servidão estão mapeadas e visíveis nos mapas dos planos regionais, ainda que não apareçam com um uso específico no mapa geral de zoneamento.

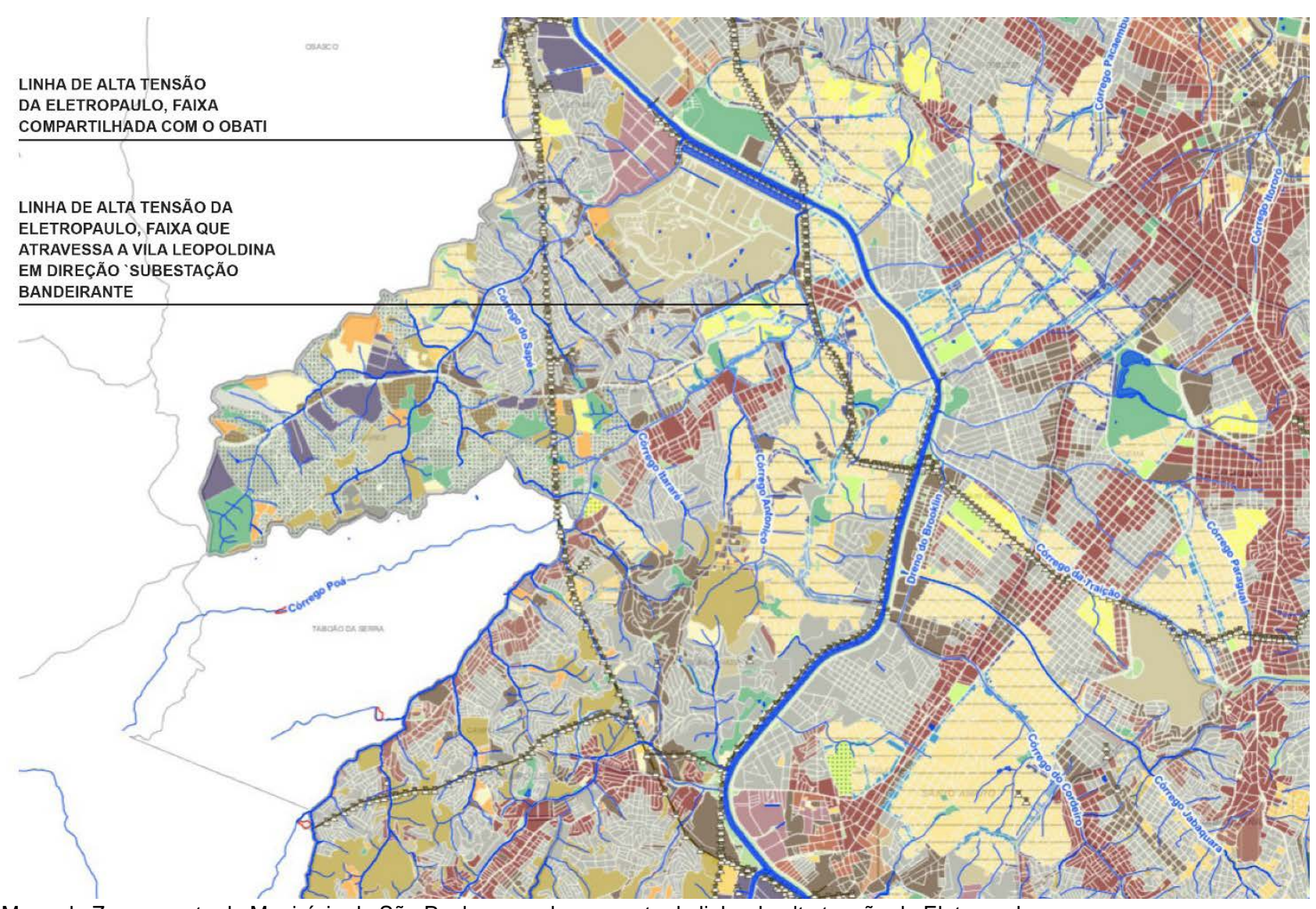

Mapa de Zoneamento do Município de São Paulo com o lançamento da linha de alta tensão da Eletropaulo.

Fonte Geosampa, Prefeitura de São Paulo (2016). Elaboração: Katia B. Pestana, 2016.

Ainda que o Plano Diretor tenha mapeado essas áreas, há um limbo entre o poder público municipal, estadual e federal e as concessionárias de serviços públicos. A prefeitura reconhece que não tem controle sobre as faixas de servidão, visto que são áreas de utilidade pública reguladas pelas agências setoriais federais; essas, por sua vez, têm o foco na cobrança de um serviço eficiente, contínuo e de boa qualidade, subordinando seu controle exclusivamente aos bens vinculados aos serviços.

Algumas análises feitas preliminarmente, respaldam pontos significativos para o avanço na pesquisa sobre 0 tema:

- Não há a aproximação necessária entre os órgãos reguladores do uso e ocupação do solo nos municípios e as concessionárias responsáveis pelos serviços públicos em busca de um melhor agenciamento do espaço público, lembrando que a instalação de parte dessa infraestrutura precedeu a legislação municipal voltada ao uso e ocupação do solo.

- Nos Planos Diretores e Regionais dos municípios por onde passa o OBATI, não há praticamente nenhuma menção à passagem do Oleoduto da Petrobrás; quando muito, faz-se alguma referência à faixa de domínio das linhas de alta tensão. 
- Como essas redes estão obrigatoriamente submetidas a condições de segurança estabelecidas por normas setoriais, os órgãos de planejamento não incorporam seu vazio 'funcional' a um plano mais amplo de agenciamento dos espaços livres da cidade.

- As questões associadas aos aspectos técnicos do funcionamento e da segurança do sistema dutoviário da Petrobrás (responsável pela manutenção da faixa non aedificandi) em comparação com outras redes de infraestrutura, tornam a interface entre essa rede e a ocupação humana descontrolada, como acontece no caso de São Paulo, um conflito peculiar, devido ao risco iminente de acidentes.

- A presença da Petrobrás, assim como das concessionárias de energia em suas faixas de operação garantiram, e ainda garantem, a atual desocupação dessas áreas.

- A documentação existente - a bibliografia, as imagens, os textos, os planos institucionais, tanto do poder público, como das concessionárias - não constitui material significativo para o desenvolvimento de uma pesquisa que procura relacionar o sistema dutoviário e o sistema elétrico com o tecido urbano. Na verdade, há uma extensa bibliografia sobre seu funcionamento, mas está centrada nos aspectos técnicos de segurança, sendo a ocupação humana um fator a mais de risco, não contribuindo com propostas de incorporação urbana do espaço funcional de sua faixa de domínio.

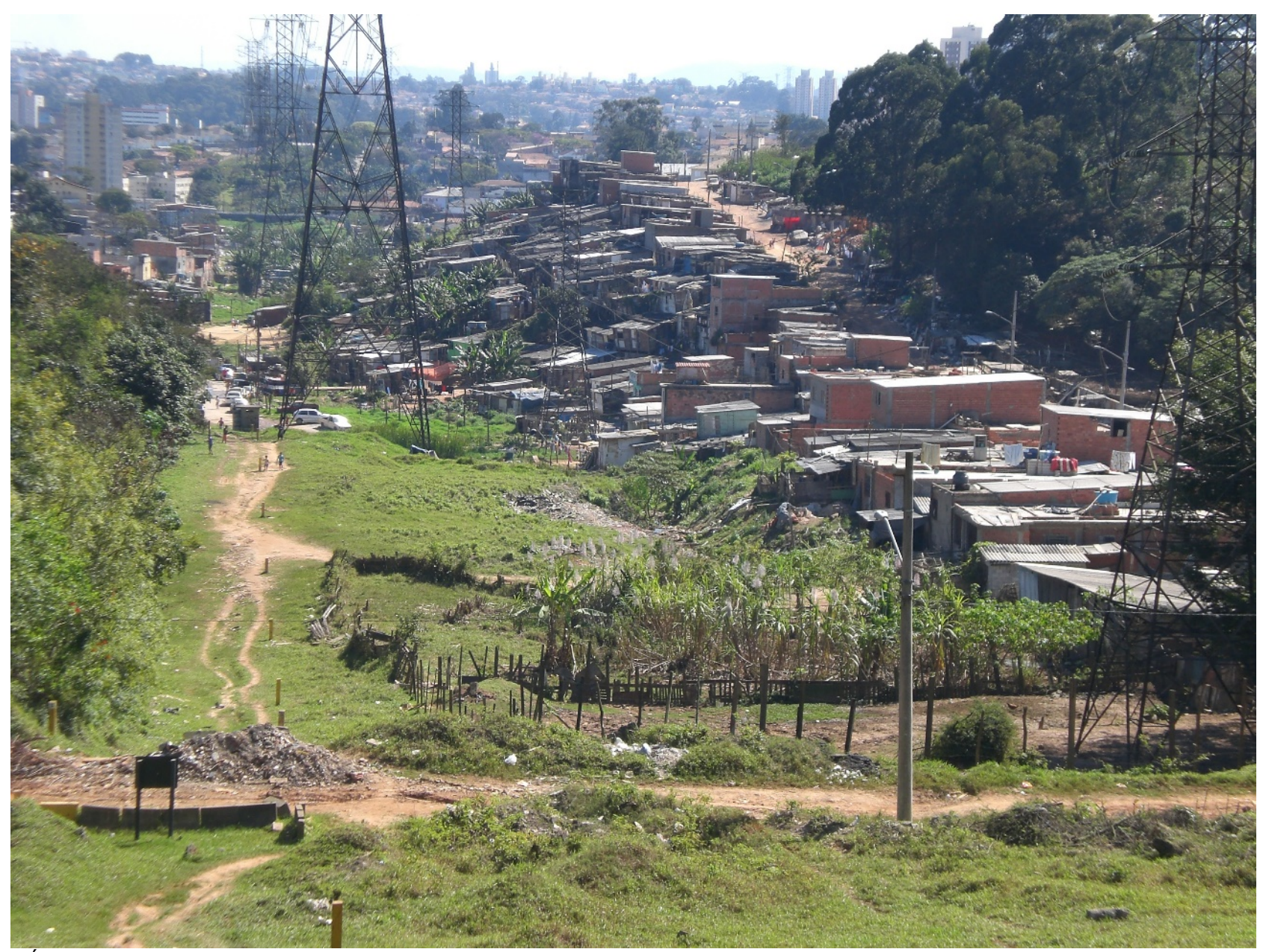

CÓRREGO DOS MIRANDAS - à esquerda os postes amarelos de sinalização da Petrobrás.

Foto: Katia B. Pestana (2010).

\section{AS REDES TÉCNICAS - OLEODUTOS E ALTA TENSÃO}

As indagações sobre o funcionamento de cada uma das redes surgem quando elas se tornam visíveis e perceptíveis na superfície que correm. Se há um interesse em compreender como elas funcionam este ocorre, sobretudo, na sua verificação com a faixa de espaço livre 'generosamente' deixada pela sua passagem. 
O objetivo de aprofundar os procedimentos dos diversos setores de infraestrutura visa compreender o funcionamento de sua lógica setorial, identificando as premissas agregadas na escolha do território, na operação e manutenção do sistema, e nos requisitos de segurança. O que se pretende com isso é alcançar uma visão mais abrangente de como essas redes de infraestrutura estabelecem sua interface com o meio em que estão inseridas, especialmente o meio urbano, para poder se avançar com algumas possibilidades de intervenção, tendo em vista as limitações impostas pelas exigências técnicas.

\subsection{O SISTEMA ELÉTRICO}

O gráfico abaixo esclarece o funcionamento do Sistema Elétrico controlado pelo Operador Nacional do Sistema Elétrico (ONS) ilustrando o caminho que faz a Energia desde as Usinas Hidrelétricas, térmicas, nucleares, eólicas, solares, etc. até os centros urbanos: Geração - Transmissão - Distribuição ${ }^{1}$.

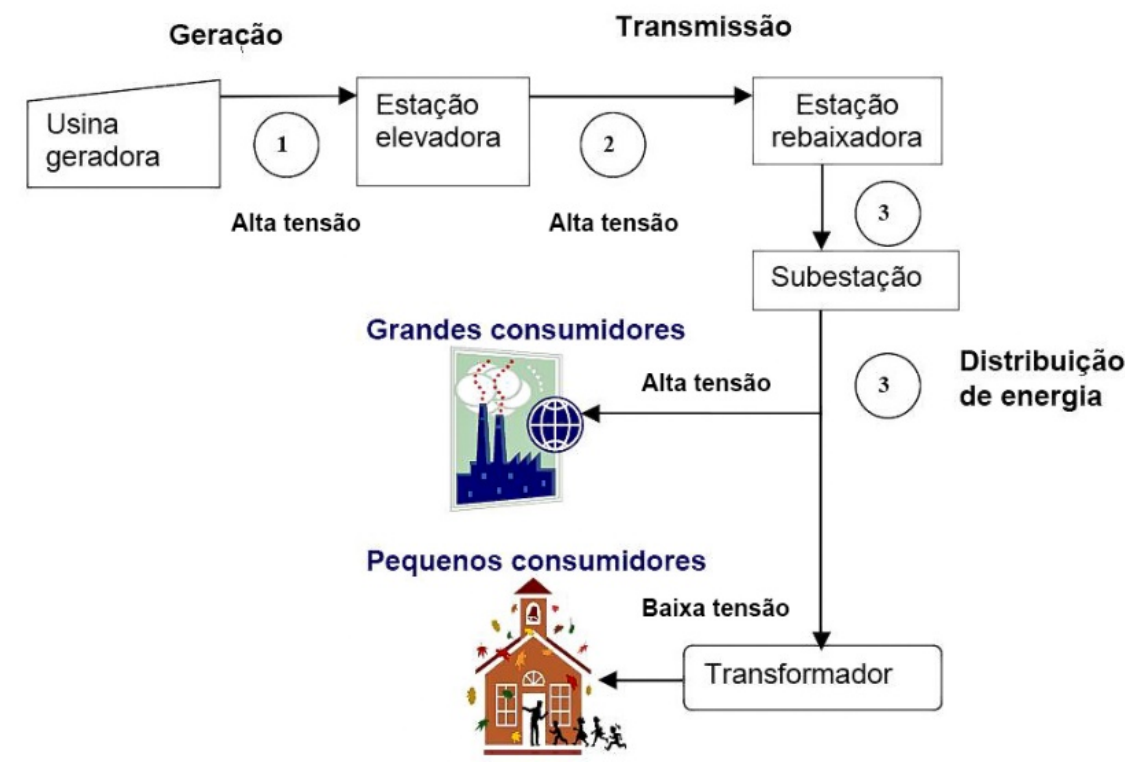

Desenho - diagrama de um sistema elétrico

FONTE: Análise e gestão de riscos das ocupações de faixas de linhas de transmissão: estudo de caso da vila alta tensão / autor: Adair Rogério de Lima. Mestrado profissional em Engenharia Geotécnica da UFOP Ouro Preto - março de 2012

Geração - No Brasil, as principais fontes de geração de energia são as hidrelétricas. Como a geração está afastada dos centros de consumo, a energia gerada precisa ter elevada o nível de tensão para sua transmissão. São as chamadas Subestações Elevadoras.

Transmissão - Com o nível de tensão elevado, é necessário a utilização de grandes torres com grandes alturas para evitar os arcos elétricos (descargas elétricas), obrigando o espaçamento maior entre as linhas, e dessas linhas com o solo. Por outro lado, é possível transportar grandes blocos de energia. Quanto maior a potência, maior a tensão, e quanto maior a tensão, maiores devem ser essas torres, a chamada Isolação. De Itaipu chegam linhas de tensões bem elevadas - 750KV/600KV.

Distribuição - Existem os grandes, os médios e os pequenos consumidores. Para cada tipo de consumidor também existe essa relação entre potência e tensão. No Brasil, há o S.I.N. - Sistema Interligado Nacional -e essa interligação deixa o sistema mais robusto permitindo coberturas e compensações de energia entre as várias fontes geradoras.

Ao chegar nos grandes centros de consumo, na distribuição, é necessário ter vários abaixamentos de tensão. Basicamente três níveis:

10. abaixamento - Subestações de maior porte - Subestação de Transmissão (ETT - Estação Transformadora de Transmissão): tensões que chegam >230 KV são abaixadas para tensões da ordem dos 138KV / 88KV. Nesse primeiro abaixamento podem ter algumas grandes indústrias - tipo Volkswagen porque tem essa relação potência / tensão. As indústrias que consomem muita potência precisam de muita tensão.

10 sistema elétrico foi explicado pelo prof. Nelson Kagan, da Escola Politécnica da Universidade de São Paulo, em entrevista concedida para o desenvolvimento da pesquisa. 
20. abaixamento - Subestações de Distribuição (Estação Transformadora de Distribuição) para tensões de $13,8 \mathrm{KV}$, a energia é distribuída entre as várias unidades. Assim acontece nos vários bairros. Há subestações espalhadas pela cidade - por exemplo, há uma subestação na Lapa, uma no Butantã, etc. - que fazem esse abaixamento da tensão para então ser distribuída para os consumidores. Esse nível de tensão chama-se Distribuição em Média Tensão ou Distribuição Primária.

3o. abaixamento - A média tensão aérea está na parte mais alta dos postes. Esse último abaixamento (Estação Transformadora ou Instalação Transformadora) é feito por transformadores que ficam nos postes na rede aérea e fazem o abaixamento da energia para baixa tensão. Essa fiação passa mais abaixo da rede de média tensão e dos transformadores, e faz a distribuição para as edificações. Essa rede também é chamada de Rede Secundária.

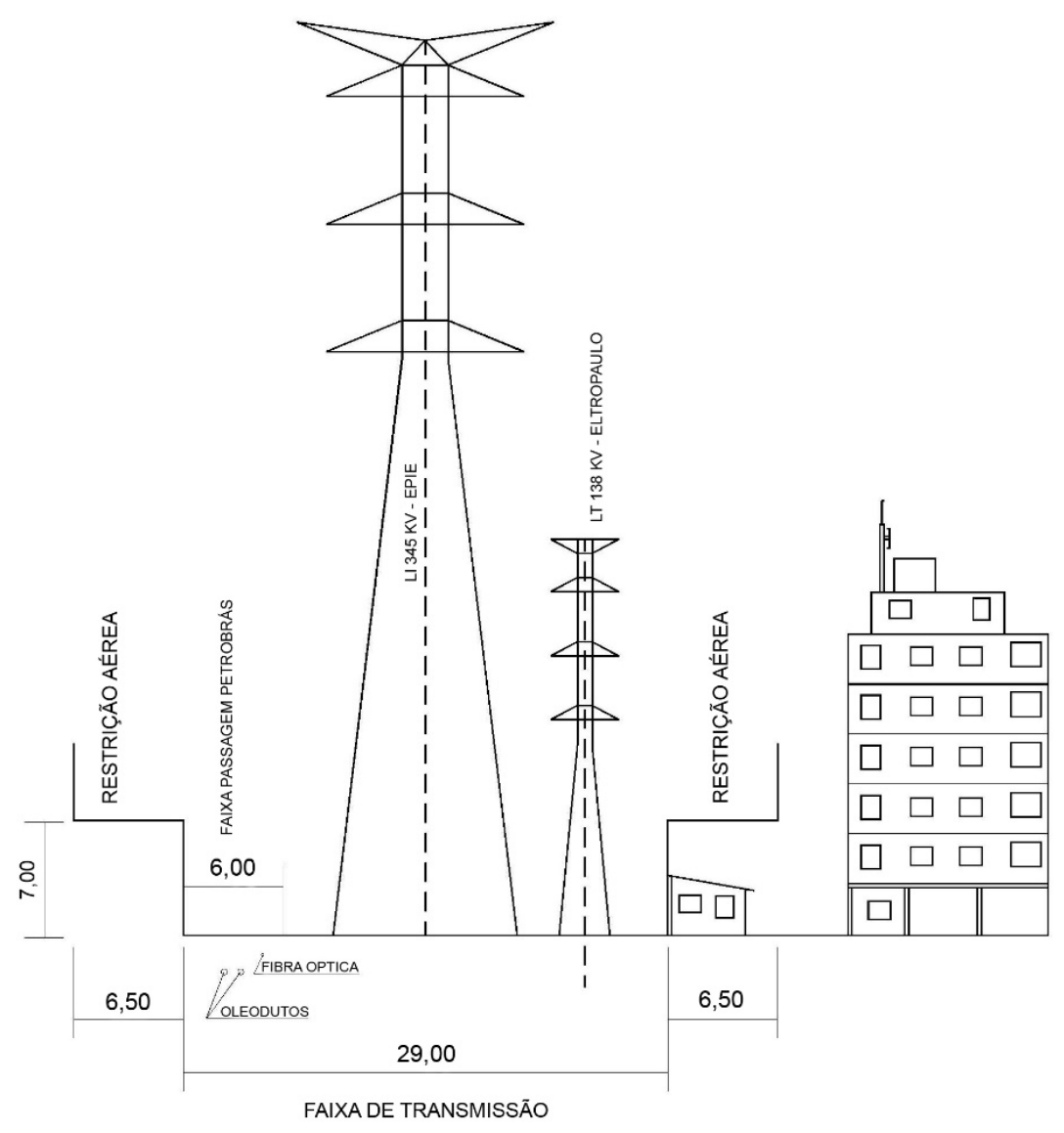

Seção típica de compartilhamento da faixa de alta tensão

Fonte: XVI SNPTEE - Grupo de estudos de Impactos Ambientais, 2001.

Portanto, quando olhamos as torres de alta tensão que passam aéreas pela cidade de São Paulo, estamos nos referindo às linhas de transmissão. Alguma dessas linhas são chamadas de transmissão básica - classe A1, e chegam com tensões muito elevadas necessitando ser abaixadas a fim de serem distribuídas aos consumidores. Essas linhas chegam com tensões maiores que $230 \mathrm{Kv}$ e entram na cidade através de torres enormes e caminham até as subestações de transmissão. Existem algumas subestações de transmissão na cidade e, certamente, lembram a surpreendente monumentalidade dessas estruturas, como disse Aleksandar Ivančić:

A lembrança da ocupação funcional abre novas perspectivas, enriquecida pela surpreendente monumentalidade e inclusive a agressividade espartana dessas estruturas, sua localização ou sua forma, pois foram criadas claramente a partir de critérios de otimização técnica e da engenharia e não tanto sob o critério da arquitetura convencional. Sua substancial inacessibilidade contribui, além do mais, para acrescentar a imagem de alienação e de monumentalidade destes corpos inertes que são as estruturas abandonadas. À espera de quem sabe, novos ocupantes se apropriem desses lugares, sua beleza surreal resulta fascinante. (IVANČIĆ: 84 ) 
Na maioria dos países, e em diversas situações, essas redes têm instalações aéreas, mas ficam na borda da cidade - os chamados "City Gates". São escalas diferenciadas que movimentam e relacionam territórios em suas várias dimensões. As grandes usinas hidrelétricas de geração de energia, além de trazer um elevado impacto ambiental, econômico e social aos lugares de sua construção, necessitam de grandes torres de transmissão em altíssima tensão para atravessar o país (às vezes fronteiras internacionais), até se aproximarem dos centros consumidores. Na região metropolitana de São Paulo, a complexidade da operação está sobretudo na distribuição, domínio das concessionárias distribuidoras de energia, como a Eletropaulo.

\subsection{O SISTEMA DUTOVIÁRIO}

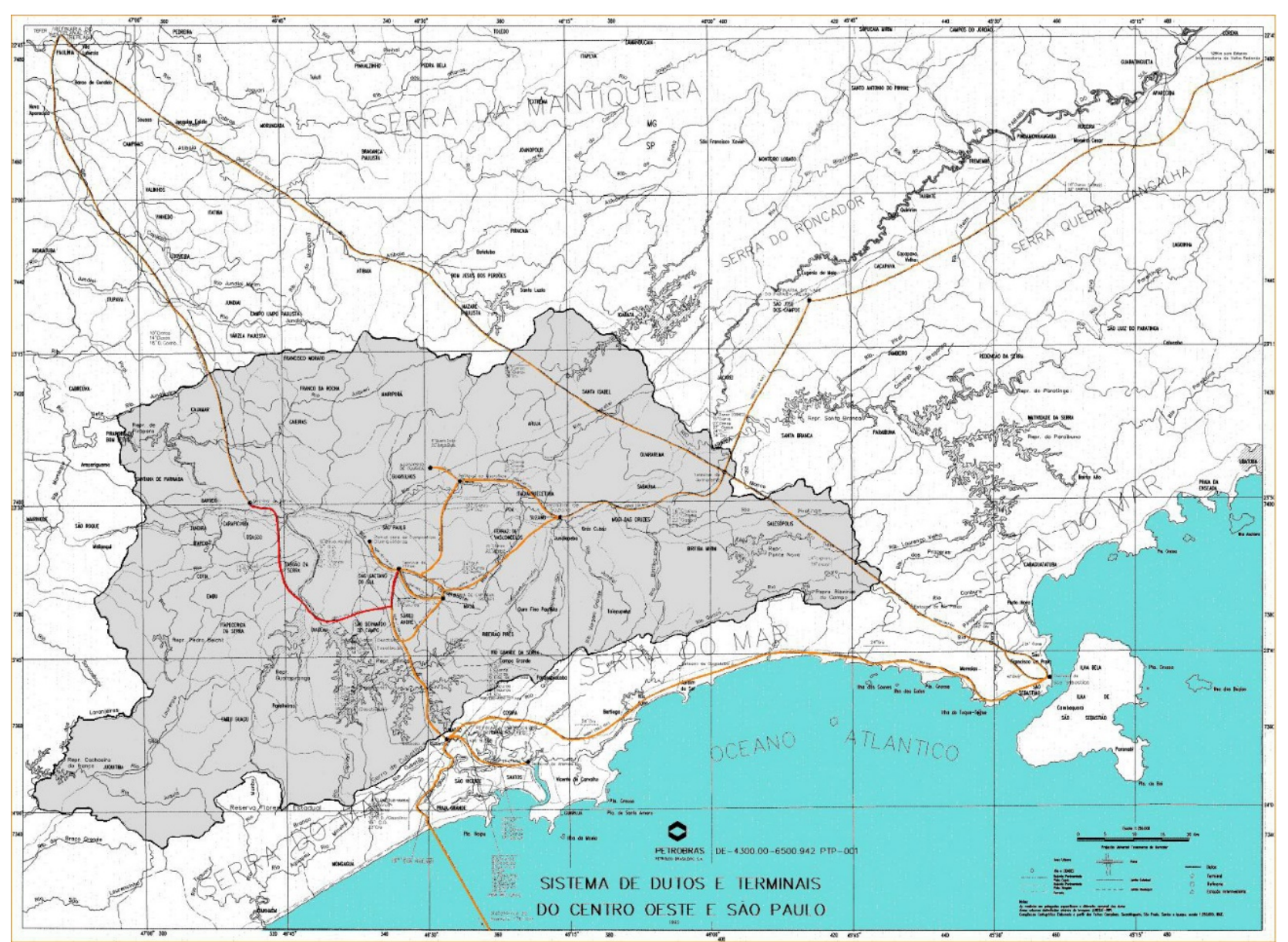

OBATI (em vermelho) no Sistema de Dutos da Petrobrás

Elaboração: Projeto Convivência e Parceria — novembro, 2001.

O primeiro oleoduto do Estado de São Paulo foi o oleoduto Santos - São Paulo, instalado na década de 50, ligando o Porto de Santos ao Terminal de São Caetano (OSSP: Oleoduto Santos / São Paulo). O OBATI começou a operar a partir de 1974, indo até Barueri. (Fonte: Transpetro).

O Sistema dutoviário foi sendo construído dos anos 1960 até os anos 1980, estabelecendo as ligações entre os centros produtores e consumidores (Bahia, Belo Horizonte, Rio de Janeiro, etc.). Os anos 1990 são marcados pela instalação de polidutos terrestres, dutos que permitem o transporte de vários tipos de produtos, pela construção do OSBRA - Oleoduto São Paulo / Brasília - e, principalmente, com grande ênfase na construção de dutos 'offshore' (dutos submarinos na Bacia de Campos, Recôncavo Baiano).

Em 1999 começa a operar o GASBOL - Gasoduto Bolívia Brasil - envolvendo os dois países e tornando-se um marco no modelo de gestão da Petrobrás. Nos anos 2000, a empresa passa a ter um crescimento substantivo e torna-se uma das maiores produtoras de petróleo do mundo.

A Petrobrás possui aproximadamente $14.873 \mathrm{~km}$ em dutos, sendo $7.719 \mathrm{~km}$ de oleodutos e $7.155 \mathrm{~km}$ de gasodutos (Fonte: Transpetro, 2017). Ao todo, possui 11 refinarias de Petróleo no Brasil, sendo quatro no Estado de São Paulo. São elas: Refinaria de Paulínia (REPLAN), Refinaria Henrique Lage - São José dos Campos (REVAP), Refinaria de Capuava - Mauá (RECAP) e Refinaria Presidente Bernardes - Cubatão 
(RBPC). São sete os terminais: São Caetano do Sul, Barueri, Alemoa, Cubatão, Guararema, Guarulhos e São Sebastião.

A rede de dutos permite que os produtos sejam transportados em duplo sentido (inversão de origem e destino do combustível), possibilitando a transferência dos produtos entre os vários pontos de produção ou porto, refino e consumo. Tanto as refinarias como os terminais estão localizados perto dos mercados consumidores e, portanto, próximos à cidade de São Paulo. Com isso, muitos oleodutos se aproximam de áreas urbanizadas ou encontram-se totalmente inseridas dentro delas, como é o caso do OBATI.

O OBATI - Oleoduto Barueri / Utinga - é um poliduto, que liga o Terminal de Barueri ao Terminal de São Caetano do Sul. Faz parte do anel dutoviário que permite o fluxo de Petróleo para o Centro-Oeste do Brasil. É constituído por dois dutos de diâmetro igual a 14" (aproximadamente $35,50 \mathrm{~cm}$ ), um que transporta produtos escuros (petróleo em estado mais bruto) e outro que transporta produtos claros (derivados de petróleo com menos viscosidade, como petroquímicos, querosene, glp etc.); possui $50 \mathrm{~km}$ de extensão e passa subterrâneo pelas regiões Oeste, Sul e Sudeste da Grande São Paulo.

A Transpetro, empresa subsidiária da Petrobrás, é a responsável pelo transporte e pela segurança da operação do oleoduto em sua integridade. Por outro lado, e reforçando a complexidade da questão, esse oleoduto passa por vários municípios e por vários bairros, atravessando pontos sensíveis social e ambientalmente.

Hoje, a Petrobrás segue as normas internacionais e investe muito na segurança de suas faixas de domínio, sendo extremamente rigorosa no controle de sua ocupação por qualquer atividade humana. Mas as normas são apenas recomendações e a tendência é que em áreas de urbanização muito precária, haja alguma flexibilidade, até para se estabelecer de um modo possível a comunicação necessária entre a população e a empresa; entre espaços carentes de infraestrutura e áreas articuladas de lazer aproveitando-se do vazio deixado pela sua passagem.

O acento que a Petrobrás vem dando à segurança e a integridade dos dutos (tanto pelas multas, cada vez mais altas, aplicadas em casos de acidentes ambientais, como pela própria imagem da empresa), a faixa de domínio por onde passa o oleoduto constitui-se sim em uma barreira urbana e deixa seu vazio por onde passa.

Inserindo o OBATI no mapa da Grande São Paulo, é possível visualizar sua extensão e a multiplicidade socioambiental, econômica, urbanística e cultural dos territórios por onde ele passa.

\section{O OBATI E A LINHA DE AT XAVANTES NA MALHA URBANA DE SÃO PAULO}

São lugares obsoletos em que certos valores residuais parecem manter-se apesar de seu completo desapego da atividade da cidade. São, em definitivo, lugares externos, estranhos, que ficam fora dos circuitos, das estruturas produtivas. Desde o ponto de vista econômico, áreas industriais, estações de trem, portos, áreas residenciais inseguras, lugares contaminados, que se converteram em áreas que pode-se dizer que a cidade já não se encontra aí. (SOLÀ-MORALES, 2002).

Quando falamos em cidade de São Paulo, referimo-nos a uma área de urbanização contínua, que inclui 39 municípios com um índice de urbanização de $96,6 \%$ e cujo centro é o Município de São Paulo (MARTINS, M. L., 2003:172).

Hoje, no início do século XXI nota-se, entre os agentes envolvidos no debate sobre as políticas urbanas, a preocupação em integrar cada vez mais as várias instâncias de poder a fim de encontrar soluções jurídicas e administrativas que possam viabilizar algum tipo de ação mais duradoura, e que projetem um futuro menos catastrófico para as grandes metrópoles. Além do Ministério das Cidades e do Estatuto da Cidade, temos o Sistema Nacional de Gestão dos Recursos Hídricos e, no nível metropolitano, os Novos Planos Diretores, o Pitu 2020, o Plano de Habitação e a Gestão da Bacia do Alto Tietê².

2 INSTITUTO ECOAR. (2001). Convivência e Parceria: construindo os caminhos da Cidadania. Caracterização e Diagnóstico socioambiental. Obati - Oleoduto Barueri - Utinga. Petrobrás. 


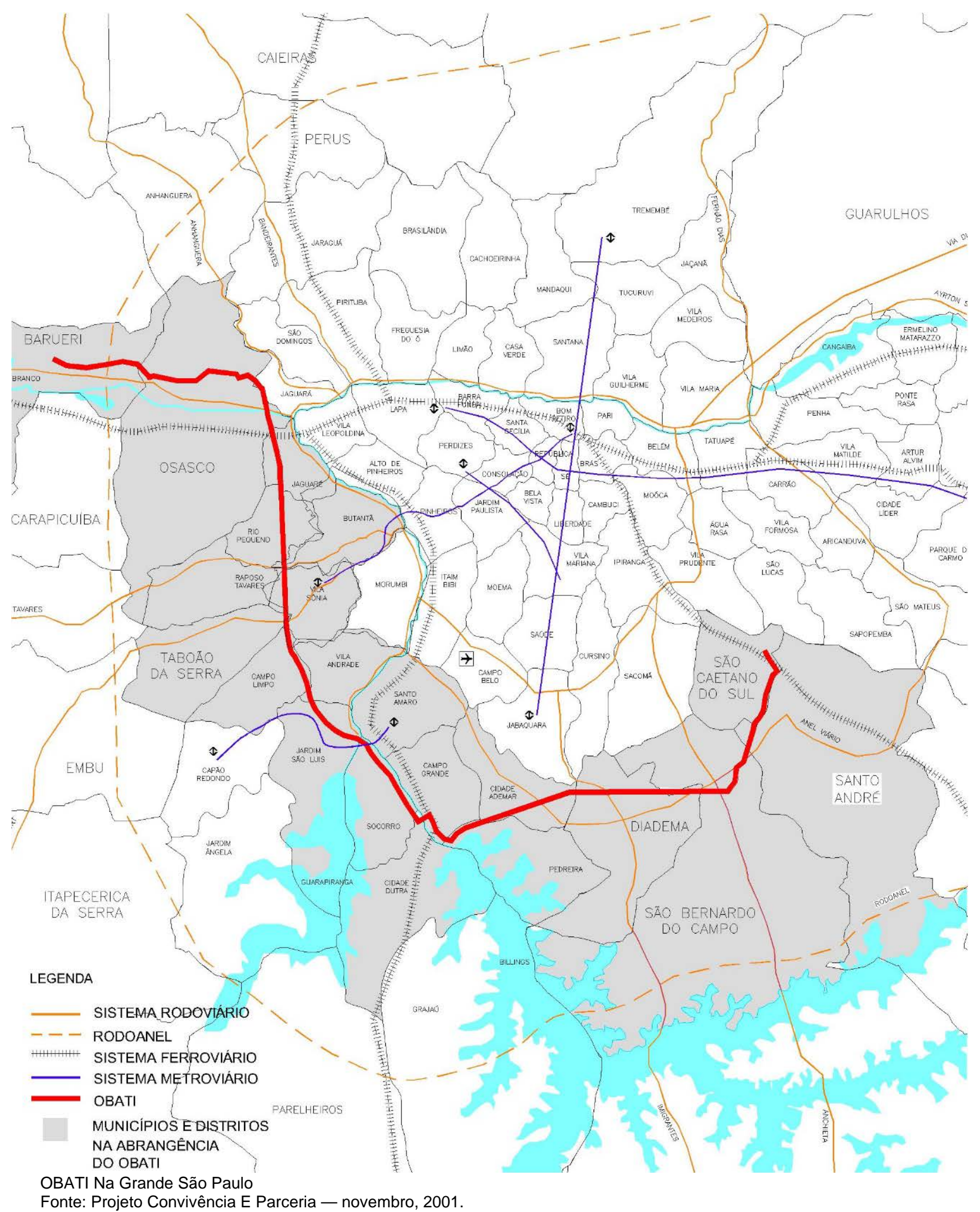

O OBATI e as linhas de AT que passam junto com ele, cruzam duas linhas de metrô, transpõem por duas vezes a linha férrea, tangenciam e cruzam o Rio Pinheiros e o Rio Tietê, aproximam-se da área de proteção aos mananciais e cruzam cinco rodovias: Castello Branco, Raposo Tavares, Regis Bittencourt, Imigrantes e Anchieta. Passam por oito municípios e onze distritos do Município de São Paulo, atravessando tanto bairros de classe média e média-alta, como áreas com ocupação de baixa renda, nas quais se incluem diversas favelas.

As conexões percebidas nas infraestruturas inseridas no tecido urbano de São Paulo, chamam a atenção por possuírem em seu traçado uma lógica sobreposta ao sistema viário de cada bairro, deixando um rastro 
desocupado, no limite entre o cuidado - porque continua vazio - e o descuido - porque a cidade não acontece ali. Nessa direção, a "fresta" deixada pela passagem do OBATI em seus $50 \mathrm{~km}$ de extensão constitui um elemento articulador e, portanto, de interesse metropolitano, devendo ser considerado como um potencial pólo gerador de espaços alternativos para o intenso e desordenado processo de urbanização verificado na Grande São Paulo.

Essas áreas, pensadas em conjunto, constituem um relevante 'Patrimônio Histórico não-edificado', o qual a cidade de São Paulo (exemplarmente) deve se apropriar. Hoje, essas linhas passam de maneira expressiva na paisagem urbana de alguns lugares e, no entanto, não há a consciência física e ambiental de sua presença.

A paisagem delineada pelas áreas situadas ao longo do OBATI e da AT XAVANTES foi sendo gradativamente ocupada, principalmente por residências, resultando em áreas densamente povoadas, marcadas por conflitos habitacionais com diferentes níveis de gravidade devido a usos não conformes e de alto impacto nas faixas dominiais. Tal processo teve lugar, sobretudo, no período que vai da década de 1970 ao início dos anos 1980, quando se consolidou a urbanização e a conseqüente ocupação das áreas contíguas às faixas de dutos.21

A pesquisa partiu da hipótese geral de que o futuro dessas redes é tornarem-se subterrâneas ou saírem do espaço mais urbanizado da cidade, algo reconhecido no prognóstico - reforçado pelo Plano Diretor de Dutos da Petrobrás ${ }^{3}$ - segundo o qual os dutos mais congestionados, expostos a um maior risco pela urbanização nos seus limites, serão desativados. O próprio OBATI tem a estimativa de ser desativado, assim que linhas alternativas previstas no plano de expansão do sistema de dutos entrarem em funcionamento. Por sua vez, as linhas de alta tensão - a rede de maior visibilidade e quantidade na cidade - são estruturas que estão previamente acomodadas no tecido urbano de São Paulo, visto serem linhas pré-existentes à urbanização adjacente à sua faixa dominial.

$\mathrm{Na}$ realidade, estas faixas existentes pela cidade são em sua maioria pertencentes às concessionárias de eletricidade que, historicamente, se instalaram primeiro. Atualmente, elas são utilizadas também para passagem de cabos de fibra ótica, o que as torna muito importantes pois passam a funcionar como calha técnica, aglutinando os serviços de infraestrutura necessários à sua distribuição pelos diversos pontos da cidade.

Evidentemente, o crescimento das cidades traz uma espécie de 'pesadelo' às empresas operadoras de dutos, ou de qualquer outra atividade que envolva risco. Por mais que se fuja, a ocupação urbana sempre se aproxima e essas redes, inicialmente projetadas para correr em meio 'rural', com requisitos de segurança mais amenos, veem-se confrontadas com uma urbanização caótica.

Isso tem particular interesse no futuro dessas faixas de servidão. Algumas infraestruturas estarão sempre ocupando essas faixas, criando novas e utilizando - sempre que possível - as vias como passagem de suas tubulações, porque são infraestruturas básicas de serviço. Outras, como os oleodutos e gasodutos de transporte, estão vinculadas a uma lógica específica e deverão incrementar suas instalações em outras direções, longe dos entraves técnicos e de segurança ocasionados pelas cidades.

De toda forma, a disponibilidade dessas faixas não edificadas no tecido urbano da cidade de São Paulo constitui-se em um patrimônio considerável. Os lugares por onde passam, a relação espacial que a população estabelece com e a partir delas, a forma como podem ser absorvidas na rede de espaços livres - tão exíguos na cidade - ampliam a questão para além do OBATI. Admite-se que sua ocupação terá sempre, primordialmente, a função de calha técnica e logicamente, a existência de oleodutos em algumas dessas faixas cria uma especificidade na forma de apropriação dos usos possíveis para elas.

Na medida em que a faixa onde corre a alta tensão e o oleoduto interfere e cria uma cicatriz no tecido urbano por onde passa, e na medida em que a ocupação do seu entorno se fez de maneira desordenada e intensa, a interação entre infraestrutura instalada e população residente traz uma questão que ultrapassa o município e ganha uma escala metropolitana: a infraestrutura passa e deixa seu rastro indelével e pernicioso na escala urbana.

Como já foi dito, o OBATI corta setores expressivos da cidade, com características muito diferenciadas entre si. Passa por bairros densamente habitados e urbanizados e, em $80 \%$ do seu percurso, acompanha as linhas de alta tensão da Eletropaulo.

O processo de urbanização ocorreu a partir de situações particulares em cada trecho, com vetores de organização do espaço transversais ao eixo da faixa, normalmente estabelecidos a partir das vias de

3 Relatório de Impacto Ambiental para O Plano Diretor de Dutos (2007).

http://www.petrobras.com.br/lumis/portal/file/fileDownload.jsp?fileld=8AF6052E409D494E0140A23BE0FD114F 
circulação. A legibilidade dessas infraestruturas como conformadoras de uma estrutura espacial única, a partir de seu vazio 'funcional', é um dos pontos de reflexão para se vislumbrar essas faixas como ordenadoras reais dos espaços livres da cidade - e estabelecer ligações entre o lugar e a metrópole.

Contudo, a compreensão do OBATI como uma estrutura contínua, que passa de modo linear no tecido urbano em seus $50 \mathrm{~km}$ de extensão, não é perceptível. Se faz necessário, então, buscar estabelecer relações objetivas do espaço existente entre o tecido urbano da cidade e a faixa de domínio específica onde correm a alta tensão e o oleoduto.

\section{ESCALAS EXEMPLARES}

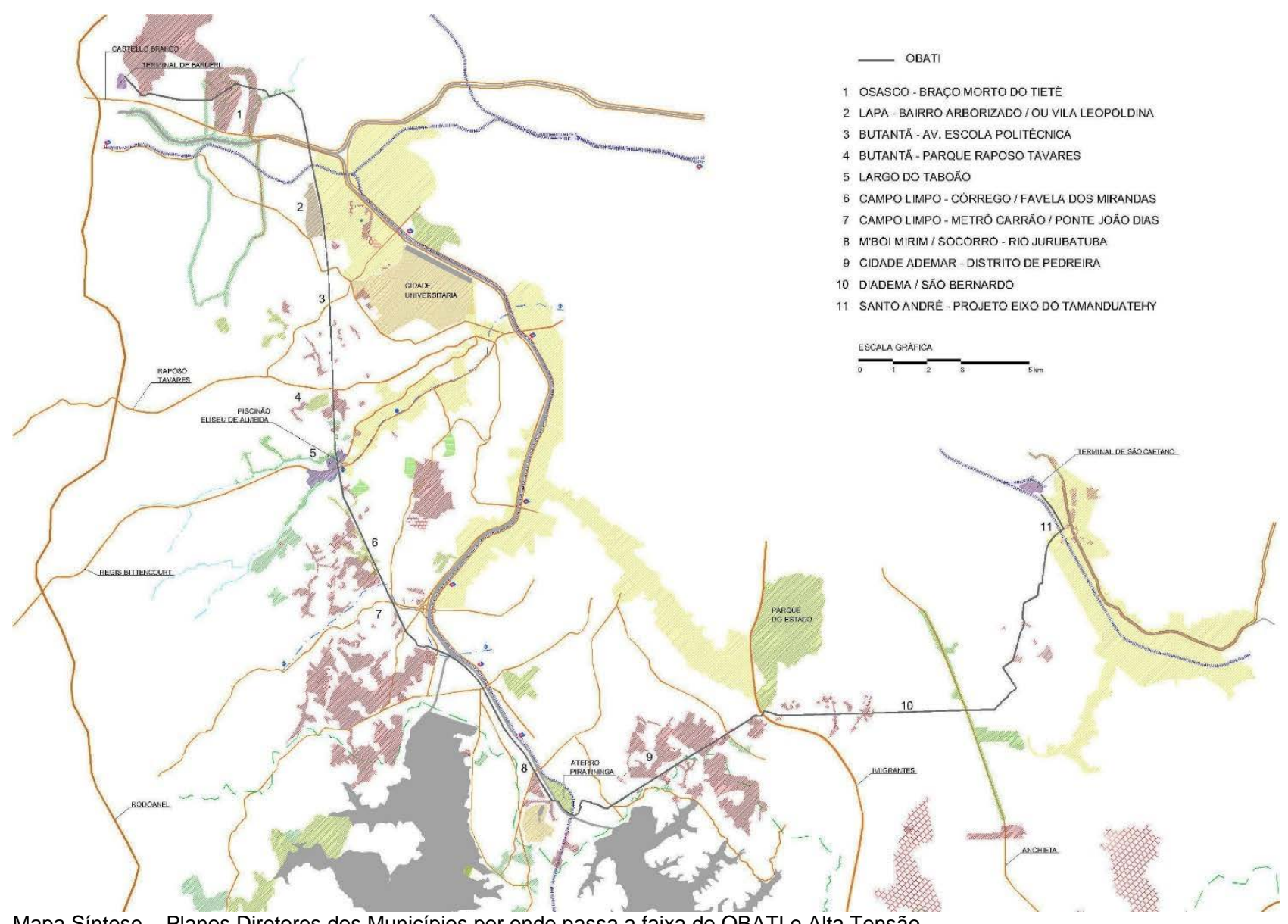

Mapa Síntese - Planos Diretores dos Municípios por onde passa a faixa do OBATI e Alta Tensão -

Principais Interferências

Elaboração: Katia Pestana — Jan/2010

\subsection{O LARGO DO TABOÃO}

O Largo do Taboão é um ponto convergente de diversas infraestruturas. Além do limite de município — o que em si não altera o tipo de ocupação -, temos o início da Regis Bittencourt, a passagem da linha de alta tensão em uma faixa bastante ampla, o Piscinão do Córrego Pirajussara (que foi alocado dentro dos limites do município de São Paulo) e o OBATI, agregado à faixa de alta tensão, com suas restrições específicas e a previsão da chegada do metrô (linha 4). Pergunta-se: Cadê o largo do Largo do Taboão?

O plano Diretor do Município acentua o caráter histórico e simbólico do Largo, sem, contudo, procurar uma equação para esse feixe de redes que o atravessa. Sua reformulação depende da articulação das outras infraestruturas existentes nesse local. A passagem de um sistema viário pesado deve ser combinada com certa urbanidade e equacionamento dos espaços públicos adjacentes; a Rodovia Regis Bittencourt é, com certeza, a infraestrutura que mais esgarça e corrompe a ideia de Largo nessa área. E a instalação do piscinão, com um desenho que se aproveita uma quadra existente, desperdiçou mais uma oportunidade de recompor o espaço público no local. 
A previsão da extensão do metrô poderia dar mais uma chance ao poder público de costurar essas redes de forma integrada, fazendo a conexão entre os setores seccionados pela Regis Bittencourt, e transformando o Largo em uma centralidade de serviços e equipamentos culturais - como recomenda o Plano - e aproveitar a sua carga histórica para dar uma identidade maior ao município.

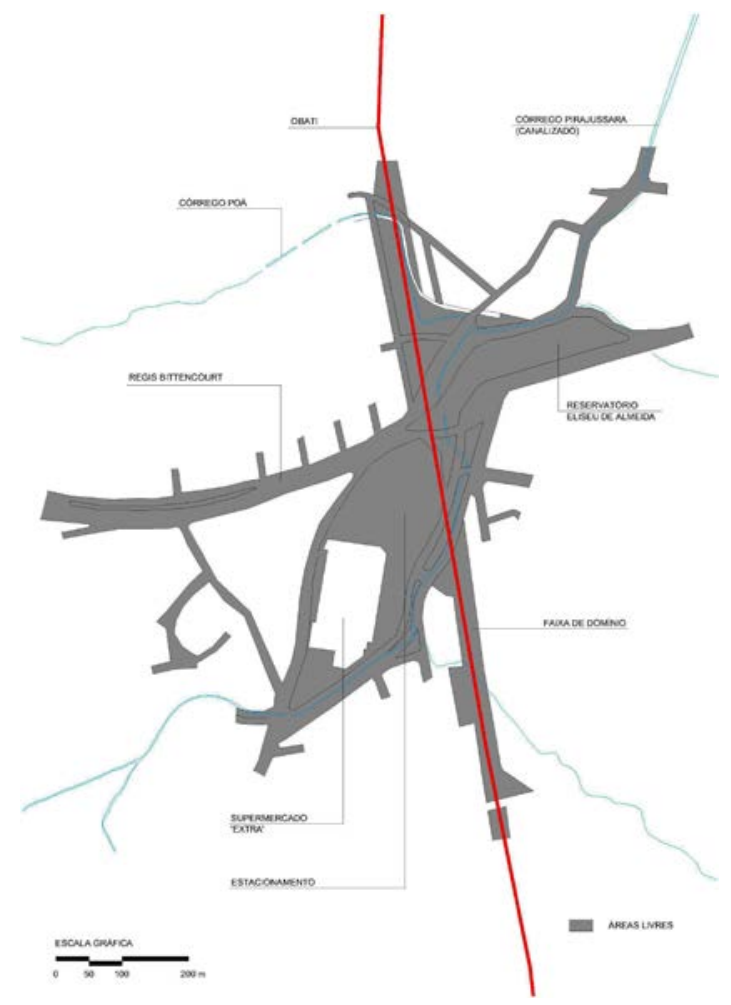

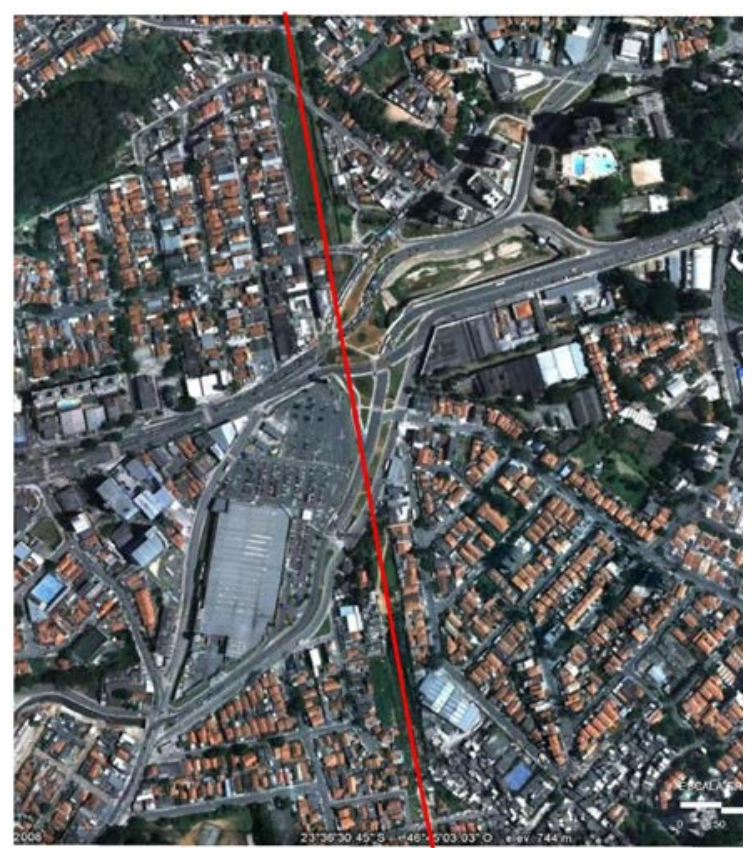

\subsection{O BRAÇO MORTO DO TIETÊ}

O braço morto do Tietê é um pequeno trecho de rio que sobrou quando foi feita a retificação do rio Tietê. Por isso mesmo, a cota de nível desse meandro é a da várzea do rio, ou seja, um local de inundações frequentes. É uma área de densa ocupação irregular e o Plano Diretor prevê ações de recuperação de suas margens, sem levar em conta a faixa funcional do oleoduto.

Nesse trecho de Osasco, o OBATI corre em faixa própria, cortando transversalmente o Braço morto e indo encontrar-se, mais adiante, com a linha de alta tensão. Existem dois ramais de linhas de alta tensão que passam paralelos por aí e atravessam a Rodovia Castello Branco e o Rio Tietê, em direção a São Paulo.

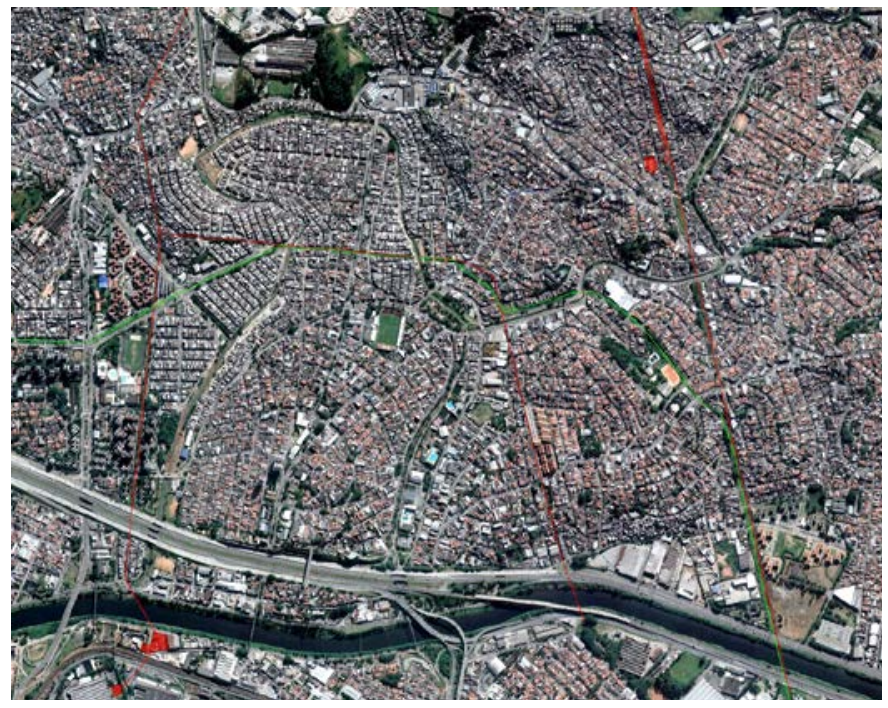

Fonte: Google, 2017.

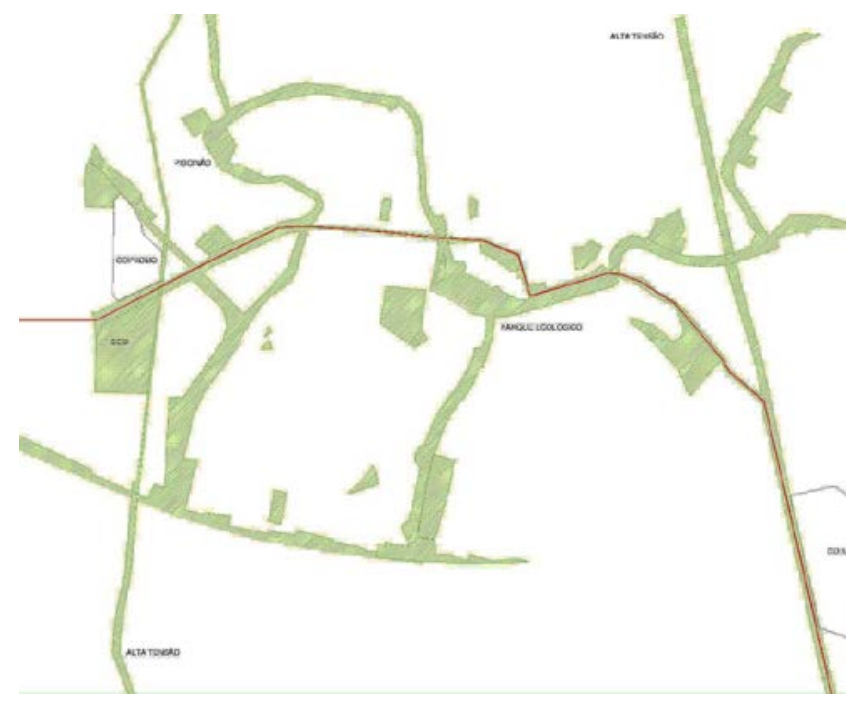

Braço Morto do Tietê em Osasco, e as possibilidades de aproveitamento dos espaços livres ligados às Infraestruturas. 


\subsection{PARQUE RAPOSO TAVARES - JARDIM JAQUELINE}

A ocupação irregular à beira dos córregos e a faixa dominial desocupada em função da vigilância constante das concessionárias.
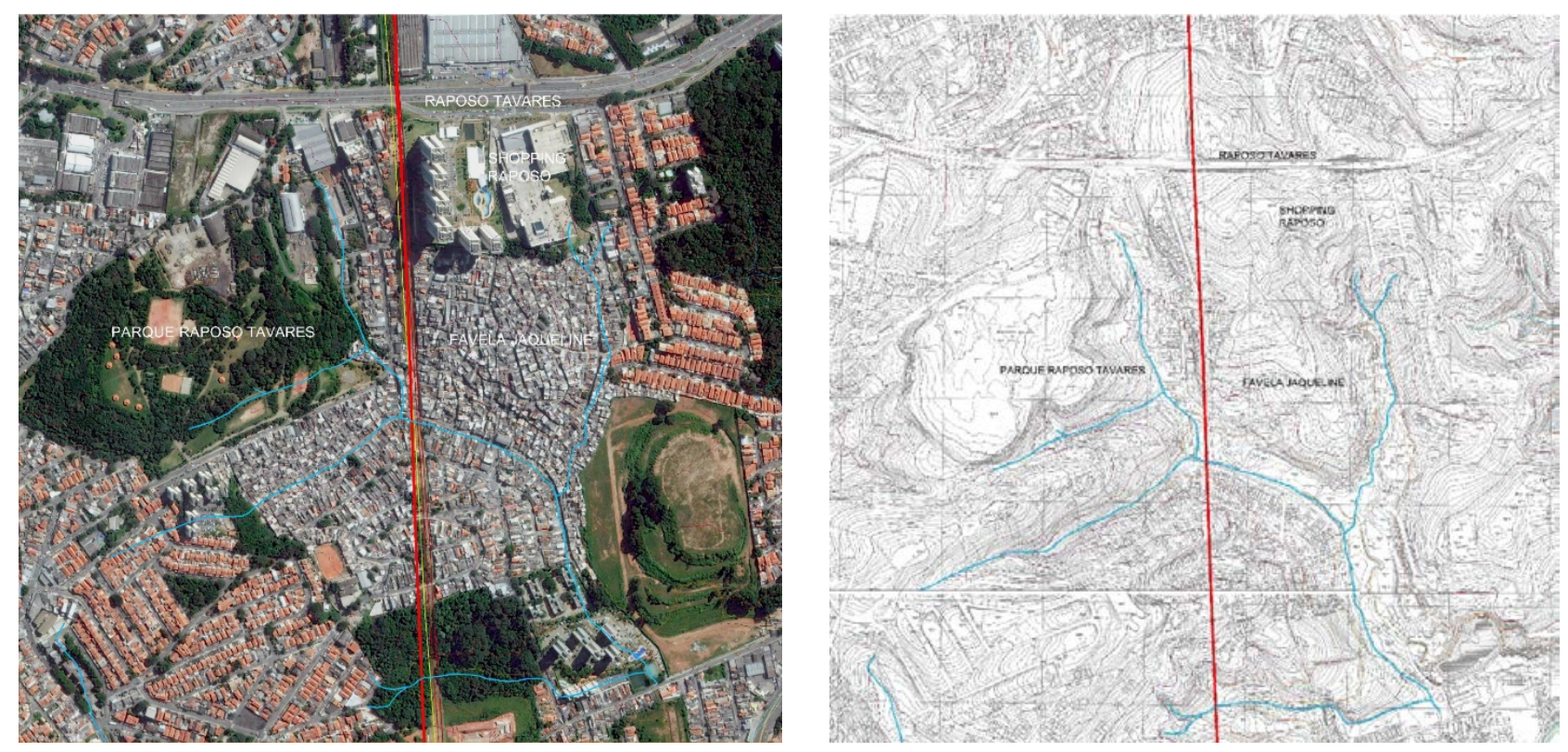

\section{CONSIDERAÇÕES FINAIS}

No estabelecimento desse recorte específico, a partir do eixo do OBATI, o trabalho se vê permeado pela pergunta: qual é especificamente o objeto de estudo: a faixa non aedificandi gerada pelo OBATI e pela linha de alta tensão ou, as faixas dos oleodutos e de outras redes urbanas, dentro das suas especificidades técnicas? Ou ainda: alternativas de ocupação de lazer dentro do espaço livre gerado pela faixa ou, do tecido urbano constituído além da faixa, visto que ela não permite usos continuados em seus limites?

São perguntas que não pretenderam ser respondidas, mas que estão subjacentes à pesquisa desenvolvida e da intenção de investigar alternativas possíveis à ocupação existente junto à faixa. É importante frisar, contudo, uma vez que isso talvez não esteja evidente, que as indagações feitas ao longo da pesquisa estiveram sempre vinculadas à ideia de que, por meio de projetos específicos, seria possível estruturar tecidos desconjuntados e, com isso, promover a melhoria urbana e ambiental das populações que vivem no entorno dessas faixas de servidão.

No entanto, pensar em projetos ficou subjacente à investigação de entendê-las minimamente, como funcionam, a que leis invisíveis - econômicas e sociais, mas também da ordem da física e da química - elas seguem para se materializar como são. Foi preciso decifrar os critérios estabelecidos para que elas passem aqui e não ali, e compreender de que maneira elas foram sendo absorvidas pelo crescimento da cidade e pela ocupação que chegou aos seus limites.

Nesse universo - de avanço tecnológico e do capital — seria possível imaginar que as linhas de alta tensão, em um futuro não muito longínquo, possam passar enterradas por estas áreas e liberar a faixa para fazer parte de um sistema de áreas livres. De qualquer forma, a vocação dessas faixas será sempre de calha técnica, mesmo considerando que essas redes evoluem tecnicamente e, cada vez mais, favorecem a ocupação sobre elas. Mas é também inquestionável que a permanência dessas áreas ainda desocupadas, é fruto da fiscalização feita pelas empresas concessionárias: a responsabilidade técnica associada à responsabilidade social é uma das discussões sobre o destino que poderão ter essas faixas e como elas poderão ser absorvidas de forma racional pelo tecido urbano existente.

Conforme Vallejo (2002), cabe às Prefeituras dos municípios, que normalmente são as responsáveis pela execução de 'obras ordinárias' na cidade, fazer o trabalho de mobilizar as empresas prestadoras de serviços públicos e apresentar propostas efetivas de intervenção, de modo a torná-las parceiras nas melhorias urbanas dos espaços públicos onde estão inseridas. 
Outro ponto que permeia o trabalho é a tentativa de distinguir o sistema dutoviário de maneira geral, das linhas de alta tensão, ou de outras infraestruturas existentes na cidade como, por exemplo, as adutoras de água da Sabesp. Destrinchar as prerrogativas técnicas dos dutos e das linhas de eletricidade permite que se faça indagações mais certeiras, visto que o trabalho se propõe a refletir, especificamente, na forma como essas infraestruturas podem ganhar legitimidade no espaço útil, vivo da cidade, e quais seriam os arranjos possíveis para integrá-las dentro da malha urbana existente nos bairros por onde ela passa.

A legislação de segurança que pesa sobre algumas dessas linhas é sempre uma fronteira para se pensar em projeto. Nesse contexto, há duas possibilidades a serem consideradas: ou bem se supõe que essas áreas permanecerão indefinidamente desocupadas e, portanto, são e serão entendidas como barreiras urbanas, e, embora não se apresentem com a contundência de uma ferrovia, por exemplo, ainda assim constituirão barreiras, muradas, isoladas e avessas a qualquer tipo de ocupação; ou cabe imaginá-las subterrâneas, permanecendo como galerias técnicas, mas propiciando, aí sim, uma ocupação mais efetiva acima delas, compondo uma estruturação de áreas livres e públicas de real uso para a população.

A viabilidade técnica, o custo operacional e a decisão política de enterrar ou remover essas redes faz parte da complexa dinâmica da política urbana de investimentos na melhoria dos espaços públicos da cidade. Há discussões em escalas diferenciadas, e as soluções possíveis vêm adensadas por muitos fatores: enterrar as linhas de alta tensão parece ser uma hipótese, ou um desejo que, se realizado, legitima uma ideia específica de cidade, baseada na urbanidade e na expansão de áreas livres, estruturas satisfatórias de serviços, ou seja, na equalização entre as várias centralidades, permitindo que os bairros já consolidados e distantes do centro expandido possam ganhar caráter. Com o enterramento, abrem-se novas fronteiras urbanas, que podem contribuir para o equilíbrio da relação entre espaço livre e público, de um lado, e as edificações, de outro, aprimorando a qualidade ambiental e urbana requeridas por lugares que se constituíram sem qualquer planejamento. Por hora, o poder de polícia das concessionárias no controle de suas faixas garante a desocupação dessas áreas.

Também é indiscutível que há uma distância entre as diretrizes das agências reguladoras, que operam apenas na lógica em que foram concebidas, voltada para os imperativos econômicos da prestação de serviços, e os municípios. A fragilidade institucional municipal reverbera aqui, talvez com o fortalecimento da instância metropolitana (Estatuto da Metrópole), seja possível cercar de forma mais efetiva a distância estratégica entre essa instância do Poder Público e as ações das empresas que operam as redes de infraestrutura.

A Petrobrás e as concessionárias de energia experimentam também as consequências de seu modo de operação. A instalação do OBATI e da linha de alta tensão no território se deu antes que a urbanização chegasse estrangulada à sua fronteira; mas hoje, o problema está posto: a urbanização foi acontecendo e as empresas veem-se, ali, no limite de sua operação. Na verdade, manter os dutos nessas áreas é a pior opção possível para todos os envolvidos nessa operação. Inclusive para a própria população.

A faixa por onde passa o OBATI, e as duas linhas de alta tensão, a da CTEEP e a da Eletropaulo, constitui, na maior parte de seu percurso, uma camada posterior de ocupação urbana - se comparada com outras redes espalhadas pela cidade - o que propicia um aumento substantivo de habitações precárias e de situações que expõem essas estruturas ao risco. Nessa faixa, o vazio afigura-se como um espaço valioso para trazer urbanidade aos lugares. No sobrevoo do Google Maps fica patente a importância que essa faixa de servidão poderia assumir para uma área onde praticamente inexistem espaços públicos que colaborem com a construção de um pertencimento àquele lugar. Os episódios em torno da faixa, e sua diversidade, são muito mais explícitos do que nas outras faixas escolhidas. É importante observar ainda que, além do oleoduto, que traz uma especificidade e uma fragilidade características, a linha da CTEEP é de altíssima tensão e percorre o tecido urbano sem nenhuma cerimônia, exigindo espaço e se sobrepondo a qualquer outra estrutura urbana que se faça necessária na região. A faixa por onde passa o OBATI é uma zona de conflito e um objeto significativo e estrutural de rearranjo de forças para equacionar o setor oeste da cidade.

Sobre esse assunto, cabe citar o Largo do Taboão como um bom exemplo. Por ali passam diversas redes com suas especificidades técnicas, inclusive o OBATI. Uma intervenção urbana nessa área necessita, obrigatoriamente, da articulação dessas redes no sentido de promover melhorias efetivas no espaço urbano. É necessário, além das especificidades do oleoduto, o aporte técnico desses outros serviços: a lógica de funcionamento dos sistemas de drenagem do 'piscinão', os requisitos de segurança das linhas de alta tensão, ou ainda as limitações técnicas das rodovias, seus raios de curvatura etc.

Isso transforma a intervenção urbana no Largo do Taboão em um projeto que deve agregar as empresas responsáveis por esses serviços e que, sob a coordenação das prefeituras (de São Paulo e Taboão), consigam fazer essa interface entre a cidade e a infraestrutura. 
No Largo do Taboão, além do sistema viário interestadual passando por ali, a instalação do piscinão naquele local, aproveitando uma quadra existente, nos remete à primeira questão colocada nessa conclusão: estamos falando de projeto para quem? Quem é o responsável pela instalação daquele piscinão nas condições em que foi implantado? Quem é que cuidou disso, o aprovou e o regulamentou?

Que projeto pode-se fazer ali, se não podemos bombardear aquele piscinão e começar tudo de novo? É uma questão de difícil solução pois, na verdade, a demanda seria dos milhares de habitantes que vivem na região e não conseguem atravessar a Regis Bittencourt, e que não encontram um largo no Largo do Taboão. Nesse caso, o OBATI deixa de ser a questão e passa a ser uma das questões a serem resolvidas na requalificação desse lugar.

Enfim, as discussões que envolvem infraestruturas como os oleodutos e as linhas de alta tensão são complexas e podem ser aprofundadas em muitos aspectos além dessa pesquisa. $\mathrm{O}$ artigo procurou trabalhar com questões gerais que pudessem introduzir a discussão sobre a interface entre essas redes e a cidade, clarificando algumas estruturas existentes entre eles, a partir da acomodação da faixa non aedificandi ao tecido urbano aonde ela está instalada.

\section{BIBLIOGRAFIA}

ARANTES, Otília B. Fiori; VAINER, Carlos; MARICATO, Ermínia. (2000). A cidade do pensamento único: desmanchando consensos. Petrópolis: Vozes.

ASSOCIAÇÃO VIVA O CENTRO. (2001). O centro das metrópoles: reflexões e propostas para a cidade democrática do século XXI. São Paulo: Editora Terceiro Nome/Viva o Centro/Imprensa Oficial do Estado.

BESSE, Jean Marc. (2006). Ver a Terra: seis ensaios sobre a paisagem e a geografia. Tradução de Vladimir Bartalini. São Paulo: Perspectiva.

BORJA, Jordi \& CASTELLS, Manuel. Local y global. La gestión de las ciudades en la era de la información. Madrid: UNCHS / Taurus, 1997.

BRAGA, Milton Liebentritt de Almeida. (2006). Infra-estrutura e projeto urbano. Tese de Doutorado, São Paulo: FAUUSP.

CAMPOS, Candido Malta. (2002). Os rumos da cidade: urbanismo e modernização em São Paulo. São Paulo: Editora SENAC.

CASTELLS, Manuel. (2007). A Sociedade em Rede. 10a ed. São Paulo: Paz e Terra.

CHOAY, Françoise. Tradução: BOUTEILLER KAVAKAMA, Eveline. (2012). O reino do urbano e a morte da cidade. Projeto História: Revista do Programa de Estudos Pós-Graduados de História, 18. Recuperado de https://revistas.pucsp.br/index.php/revph/article/view/10977/8097

DELIJAICOV, Alexandre. Os rios e o desenho urbano da cidade: proposta de projeto para a orla fluvial da Grande São Paulo. Dissertação de Mestrado. FAUUSP, 1998

DEMATTEIS, Giuseppe. (2004). Em la encrucijada de la territorialidad urbana. In: RAMOS, A. M. (Ed.). Lo Urbano en 20 Autores Contemporáneos. Barcelona: Edicions UPC.

DINIZ, Renato. (2012). 100 anos de história e energia. São Paulo: Via das Artes.

ELETROPAULO. (1990). A Cidade da Light: 1899-1930. São Paulo: Superintendência de Comunicação / Departamento de Patrimônio Histórico / Eletropaulo, 2v.

FILARDO JR., Angelo S. (1998) Territórios da eletricidade. A Light em São Paulo e o Projeto da Serra de Cubatão - 1925-1950. Dissertação de Mestrado. São Paulo: FAUUSP.

FRANCO, Fernando de Mello. (2005). A construção do Caminho. A estruturação da Metrópole pela conformação técnica das várzeas e planícies fluviais da Bacia de São Paulo. Tese de Doutorado. São Paulo: FAUUSP.

FREIRE, José Luiz de França (org) (2009). Engenharia de dutos. Rio de Janeiro: ABCM.

GRAHAM, Stephen; MARVIN, Simon. (2001). Splintering urbanism. Nova York: Routledge.

INSTITUTO ECOAR. (2001). Convivência e Parceria: construindo os caminhos da Cidadania. Caracterização e Diagnóstico socioambiental. Obati - Oleoduto Barueri - Utinga. Petrobrás.

IVANČIĆ, Aleksandar. Energyscapes. Barcelona: Gustavo Gilli, 2010. 
LANGENBUCH, Jurgen Richard. A estruturação da grande São Paulo, estudo de geografia urbana. Rio de Janeiro: IBGE, 1971.

LEITE, Maria Angela P. Um sistema de espaços livres em São Paulo. Estudos Avançados, vol. 25, no. 71 , janeiro/abril 2011.

MAGALHÃES, Gildo (Org.). História e energia: memória, informação e sociedade. São Paulo: Alameda, 2012.

MARANDOLA Jr., Eduardo; HOLZER, Werther; OLIVEIRA, Lívia. Qual é o espaço do lugar? São Paulo: Perspectiva, 2014.

MARICATO, Ermínia. Brasil, cidades: alternativas para a crise urbana. Petrópolis: Vozes, 2001.

MARTINS, Maria Lucia Refinetti. (2003). São Paulo: além do plano diretor. Estudos Avançados, 17(47), 167186. http://dx.doi.org/10.1590/S0103-40142003000100010.

MENESES, Ulpiano T. Bezerra de. (2001). Prefácio: Cidade Capital, Hoje? In: SALGUEIRO, Heliana Angotti (Org.) Cidades capitais do século XIX. São Paulo: Edusp.

(2006). A cidade como bem cultural - Áreas envoltórias e outros dilemas, equívocos e alcance na preservação do patrimônio ambiental urbano. in: MORI, Victor Hugo; SOUZA, Marise Campos de; BASTOS, Rossano Lopes; GALLO, Haroldo (Orgs.). Patrimônio: Atualizando o debate. São Paulo: 9a SR I IPHAN.

MEYER, Regina Maria Prosperi; GRONSTEIN, Marta Dora; BIDERMAN, Ciro. (2004). São Paulo metrópole. São Paulo: Edusp/Imprensa Oficial do Estado de São Paulo.

; GRONSTEIN, Marta Dora. (2010) A leste do centro: territórios do urbanismo. São Paulo: Imprensa Oficial do Estado de São Paulo.

. (2015). São Paulo e as escalas de sua urbanização: a cidade, a metrópole e a

macrometrópole. Revista Iberoamericana de Urbanismo (riURB), $\mathrm{n}^{\circ} 12$.

(http://www.riurb.com/n12/12_01_Meyer.pdf).

MOREIRA, Renata M. P. Distribuição de água na região metropolitana de São Paulo: Tecnologias da Universalização e produção do espaço. Dissertação de Mestrado. São Paulo: FAUUSP, 2008.

NIEMEYER, Oscar. Parque do Tietê: Plano de reurbanização da margem do Rio Tietê. São Paulo: Almed, 1986.

OHTAKE, Massashi Ruy. Parque ecológico do Tietê. São Paulo: Ecourbs, 1976.

PESTANA, Katia B. OBATI: Oleoduto Barueri-Utinga. Estudos e alternativas de re-ordenação de sua faixa lindeira. Dissertação de Mestrado. São Paulo: FAUUSP, 2010.

RAMOS, A. M. (Ed.). Lo urbano en 20 autores contemporáneos. Barcelona: Edicions UPC, 2004

REIS FILHO, Nestor Goulart. (2006). Notas sobre urbanização dispersa e novas formas de tecido urbano. São Paulo: Via das Artes.

(2010). Dois séculos de projetos no estado de São Paulo: Grandes obras e urbanização. São Paulo: Edusp/Imprensa Oficial do Estado de São Paulo.

ROLNIK, Raquel. A cidade e a lei: legislação e política urbana e territórios na cidade de São Paulo. São Paulo: Nobel/Fapesp, 1999.

ROWE, Colin; KOETTER, Fred. Collage city. Cambridge e Londres: The MIT Press, 1978.

SANTOS, Milton. A natureza do espaço: técnica e tempo, razão e emoção. São Paulo: HUCITEC, 1996.

SCOPPETTA, Cecília. Il territorio come infrastruttura. TeMA, Journal of Land Use, Mobility and Environment, vol.5, Abril 2012.

SECCHI, Bernardo. Primeira lição de urbanismo. São Paulo: Perspectiva, 2006.

SEMINÁRIO INTERNACIONAL HISTÓRIA E ENERGIA 2., 1999, São Paulo. Potencial estratégico de cultura e negócios. São Paulo: Fundação Patrimônio Histórico da Energia de São Paulo, 2000.

SILVA, Ricardo Toledo; PORTO, Mônica Ferreira do Amaral. Gestão Urbana e gestão das águas: caminhos da integração. Estudos Avançados, vol.17, nº. 47, janeiro/abril 2003. 
SOLÀ-MORALES, Ignasi de. (2002). Terrain Vague. In: Territorios. Barcelona: Editorial Gustavo Gili. (2009). Los artículos de Any. Barcelona: Fundación Arquia,.

VARNELIS, Kazys. The infrastructural city. Barcelona: Actar, 2008.

VILLAÇA, Flávio. Espaço intra-urbano no Brasil. São Paulo: Nobel, 2001.

VALLEJO, Manuel Herce; FARRERONS, Joan Miró. El soporte infraestructural de la ciudad. Barcelona: Edicions UPC, 2002.

. Infraestructuras y médio ambiente, vol. I e II. Barcelona: Editorial UOC, 2010. 